\title{
Diagnosis and isolation of Toxoplasma gondii in horses from Brazilian slaughterhouses
}

\author{
Diagnóstico e isolamento de Toxoplasma gondii em equídeos de frigoríficos brasileiros \\ Fernanda Evers ${ }^{1}$; João Luis Garcia ${ }^{2}$; Italmar Teodorico Navarro ${ }^{2}$; Dauton Luiz Zulpo ${ }^{3}$; Beatriz de Souza Lima Nino \\ Maria Paula de Carvalho Ewald ${ }^{1}$; Sthefany Pagliari ${ }^{1}$; Jonatas Campos de Almeida ${ }^{1}$; Roberta Lemos Freire ${ }^{2 *}$ \\ ${ }^{1}$ Programa de Pós-graduação em Ciência Animal, Universidade Estadual de Londrina - UEL, Londrina, PR, Brasil \\ ${ }^{2}$ Departamento de Medicina Veterinária Preventiva, Centro de Ciências Agrárias, Universidade Estadual de Londrina - UEL, \\ Londrina, PR, Brasil \\ ${ }^{3}$ Laboratório de Parasitologia e Imunologia, Pontifícia Universidade Católica do Paraná - PUC, Toledo, PR, Brasil \\ ${ }^{4}$ Laboratório de Zoonoses e Saúde Pública, Departamento de Medicina Veterinária Preventiva, Universidade Estadual de Londrina - UEL, \\ Londrina, PR, Brasil
}

Received May 4, 2012

Accepted October 29, 2012

\begin{abstract}
This study aimed to investigate anti-Toxoplasma gondii antibodies and to isolate the parasite from the brains of horses processed at slaughterhouses in Brazil. We collected brain and blood samples from 398 horses of various ages, from six Brazilian states. Serum samples were evaluated by indirect fluorescent antibody test (IFAT cut-off titre $\geq 1: 64$ ), and brains were submitted to mouse bioassay. Among the 398 horses, positivity for T. gondii was identified in 46 (11.6\%) by IFAT and in $14(3.5 \%)$ by mouse bioassay. In 12 of those 14 bioassays, mice were positive only by IFAT (cut-off titre $\geq 1: 16$ ), T. gondii being isolated in the remaining two. Using polymerase chain reaction-restriction fragment length polymorphism (PCR-RFLP) analysis of $18 \mathrm{~S}$ rDNA to differentiate among T. gondii, Neospora caninum, and Sarcocystis neurona, we found that two of the 14 brains were positive for T. gondii only. For genotyping of the two isolates and the PCR-positive brain, we performed PCR-RFLP based on 13 markers, and SAG2 all samples were Toxoplasma gondii type I. Collectively, IFAT of horse sera and mouse bioassay identified positivity in $60(15 \%)$ of the samples. Our results show that some horses sent to slaughter in Brazil have been exposed to T. gondii.
\end{abstract}

Keywords: Slaughterhouse, horses, Toxoplasma gondii, bioassay, indirect fluorescent antibody test, nested PCR-RFLP.

\section{Resumo}

O objetivo do estudo foi investigar anticorpos anti-Toxoplasma gondii e isolar o parasita do cérebro de equídeos abatidos em matadouros-frigoríficos no Brasil. Colheram-se amostras de 398 cérebros e sangue de equídeos machos e fêmeas de idades variadas, provenientes de seis estados brasileiros. As amostras de soro foram avaliadas pelo teste de imunofluorescência indireta (IFI) para T. gondii (ponto de corte $\geq 64$ ), e os fragmentos de cérebros foram submetidos ao bioensaio em camundongos. Por meio da IFI, 46 (11,6\%) equídeos foram soropositivos. Pelo bioensaio em camundongos, 14 (3,5\%) cérebros de equídeos testados foram positivos. Em doze dos bioensaios, os camundongos foram positivos somente pela IFI (ponto de corte $\geq 16$ ) e T. gondii foi isolado nos outros dois bioensaios. A PCR-RFLP com base em 18S rDNA para diferenciar entre T. gondii, Neospora caninum, e Sarcocystis neurona foram feitas em todos os 14 cérebros e dois foram positivos apenas para T. gondii. De dois isolados positivos para $T$. gondii e do cérebro positivo à PCR em que realizou-se a PCR-RFLP, com base em 13 marcadores e SAG2, a genotipagem mostrou ser o T. gondii tipo I para todas as amostras. A IFI de soros de equídeos e do bioensaio em camundongos identificaram positividade em $60(15 \%)$ amostras testadas. Os resultados mostram que alguns cavalos enviados para abate foram expostos ao T. gondii.

Palavras-chave: Abate, equídeos, Toxoplasma gondii, bioensaio, imunofluorescência indireta, nested PCR-RFLP.

\footnotetext{
${ }^{*}$ Corresponding author: Roberta Lemos Freire

Departamento de Medicina Veterinária Preventiva, Centro de Ciências Agrárias,

Universidade Estadual de Londrina - UEL, Rod. Celso Garcia Cid (PR 445),

Km 380, CP 6001, CEP 86051-990, Londrina, PR, Brasil

e-mail: rlfreire@uel.br
} 


\section{Introduction}

In Brazil, horses are bred for sport and recreation rather than for slaughter. Prejudice has traditionally been the principal factor limiting the human consumption of horse meat. This is because, as in many other countries, horses are viewed as pets. However, Brazil has legal provisions allowing the slaughter of horses, as well as the packaging and distribution of horse meat, including a requirement that products containing horse meat be so labelled (JUNQUEIRA et al., 2005).

According to data from the Federal Food Safety and Inspection Service of the Brazilian National Ministry of Agriculture, Animal Husbandry, and Supply (BRASIL, 2012), horse meat is produced by five slaughterhouses, all of which are licensed to export that meat: one in the state of Rio Grande do Sul; two in the state of Paraná; one in the state of Minas Gerais; and one in the state of Bahia. Horse meat is obtained from horses that can no longer work or breed and is produced exclusively for export, because the Brazilian market for horse meat is virtually nonexistent (TORRES; JARDIM, 1987; JUNQUEIRA et al., 2005).

According to Inacio (2010), Brazil ranks fourth among the world's horse meat exporters, accounting for $10.9 \%$ of all such export, after Argentina (28.7\%), Canada (24.6\%), and Poland (14.6\%). In 2005, the state of Paraná accounted for $47 \%$ of all horse meat exports from Brazil, followed by the states of Rio Grande do Sul, Minas Gerais, and São Paulo (MEDEIROS, 2009).

Contrary to what occurs in Brazil, the use of horse meat for human consumption is a common practice in European and Asian countries, creating a global market and raising concern regarding the consumption of raw or undercooked meat from infected horses, which can be a major route of transmission of Toxoplasma gondii.

A recently reported case of congenital toxoplasmosis in a newborn in France where a pregnant woman who was seropositive for $T$. gondii (due to immunization against toxoplasmosis prior to pregnancy) was reinfected, probably after having consumed raw horse meat imported from South America (ELBEZ-RUBINSTEIN et al., 2009) underscores the importance of evaluating the epidemiology of $T$. gondii in exported horse meat.

The prevalence of toxoplasmosis in horses varies by region, diagnosis, and cut-off point. Previous studies have indicated that seropositivity for T. gondii in horses ranges from $1.5 \%$ to 33\% (LARANGEIRA et al., 1985; VIDOTTO et al., 1997; GARCIA et al., 1999; MENDONÇA et al., 2001; NAVES et al., 2005; CAMOSSI et al., 2010).

Polymerase chain reaction-restriction fragment length polymorphism (PCR-RFLP) is used worldwide to determine the genotype diversity of $T$. gondii, as it was in studies conducted by Pena et al. (2008), Dubey and Su (2009), and Yai et al. (2009). Those authors concluded that there is a high diversity in the strains found in Brazil, and none of them observed the type II genotype. However, Macedo et al. (2012) and Da Silva et al. (2011) recently described the type II genotype in cattle and sheep in Brazil, respectively.

The objectives of the present study were to investigate the prevalence of anti- $T$. gondii antibodies in horses processed at slaughterhouses in Brazil and to isolate the parasite from the brains of those horses.

\section{Materials and Methods}

\section{Collection site and sampling}

We collected samples from horses processed at two slaughterhouses, the horse meat batches having been randomly chosen by the Paraná State Branch of the Federal Food Safety and Inspection Service. The target population consisted of approximately 4000 horses. The minimum sample size, as calculated with Epi Info, version 6.04 (DEAN et al., 1994), on the basis of an estimated prevalence of $50 \%$, an error of $5 \%$, and a significance level of $5 \%$, was found to be 384 individuals. We defined the prevalence of $50 \%$ to calculate the sample size to determine the prevalence of antibodies against various diseases. The protocols employed in the present study were approved by the Animal Experimentation Ethics Committee of the (Paraná) State University at Londrina, located in the city of Londrina, Brazil (Protocol nos. 59/09 and 60/09).

\section{Blood and brain collection}

Between July of 2009 and January of 2010, adult horses of various ages were selected from among those arriving from the following states and cities in Brazil:

- State of Paraná $(\mathrm{N}=152)$ - cities of Apucarana $(\mathrm{n}=4)$, Araruna $(\mathrm{n}=4)$, Borrazópolis $(\mathrm{n}=4)$, Cafezal do Sul ( $\mathrm{n}=15)$, Campina Grande do Sul $(\mathrm{n}=27)$, Imbituva $(\mathrm{n}=13)$, Londrina $(\mathrm{n}=3)$, Lobato $(\mathrm{n}=33)$, Marquinho $(\mathrm{n}=12)$, Novo Itacolomi $(\mathrm{n}=7)$, Prudentópolis $(\mathrm{n}=12)$, Ribeirão Claro $(n=9)$, Rio Bom $(n=2)$, São João do Ivaí $(\mathrm{n}=3)$, and Santa Fé $(\mathrm{n}=4)$;

- State of Minas Gerais $(\mathrm{N}=53)$ - cities of Frutal $(\mathrm{n}=33)$ and Itapagipe $(\mathrm{n}=20)$;

- State of Rio de Janeiro (N=39) - city of Italva;

- State of Goiás $(\mathrm{N}=6)$ - city of of Caiapônia;

- State of Mato Grosso do Sul ( $\mathrm{N}=99)$ - cities of Coronel Sapucaia $(n=10)$, Deodápolis $(n=21)$, Paranaíba $(n=22)$, and Rio Verde de Mato Grosso ( $\mathrm{n}=46)$; and

- State of Mato Grosso ( $\mathrm{N}=49)$ - cities of Cáceres $(\mathrm{n}=20)$, Canarana $(\mathrm{n}=12)$, and Cuiabá $(\mathrm{n}=17)$.

The horses were selected through systematic sampling, random selection having been carried out daily, depending on the demand at the slaughterhouses.

After the horses had been stunned and exsanguinated, we collected 10-mL blood samples, from each of 398 horses. After clot retraction, the serum was placed in $1.5-\mathrm{mL}$ polyethylene tubes and stored at $-15^{\circ} \mathrm{C}$ for subsequent serology. Approximately $50 \mathrm{~g}$ of brain tissue were collected from each horse. The brain samples were individually stored in isothermal boxes and sent to the State University at Londrina to be analyzed in the Laboratory of Zoonoses and Public Health and in the Protozoology Laboratory.

\section{Indirect Fluorescent Antibody Test}

The presence of anti- T. gondii antibodies in serum was detected by Indirect Fluorescent Antibody Test (IFAT), in accordance with the method proposed by Camargo (1974). We used RH 
tachyzoites as antigen, as well as anti-IgG conjugates (Sigma Chemical, St. Louis, MO, USA), together with positive and negative controls for horse and mouse sera. Positivity was defined as a titre $\geq 1: 16$ for mice (TSUTSUI et al., 2007) and $\geq 1: 64$ for horses (GARCIA et al., 1999).

\section{Mouse bioassay for the detection of T. gondii}

Brain samples from horses were macerated prior to their use in mouse bioassays for the detection of $T$. gondii. All mice used for bioassays were Swiss-Webster albino females weighing approximately $20-25 \mathrm{~g}$. Each processed brain sample was used in order to inoculate two mice intraperitoneally with $1 \mathrm{~mL}$ of the sample. Over a six-week period, the mice were observed for clinical signs of infection (ruffled fur or prostration). When one or more clinical signs were observed, the mouse was killed and peritoneal fluid was collected. Fluid samples were mounted on slides, coverslipped, and screened for tachyzoites under light microscopy. After six weeks, we killed all of the surviving mice, after which we collected blood samples for IFAT and brain tissue samples for detection of tissue cyst formation under light microscopy (NAVARRO et al., 1992; DUBEY et al., 1995).

\section{PCR-RFLP}

The samples that were found to be positive for $T$. gondii by mouse bioassay were submitted to DNA extraction with the DNeasy Blood \& Tissue Kit (QIAGEN, Hilden, Germany) and PCR-RFLP analysis of 18 S rDNA (SU et al., 2010), which amplifies a 291-bp fragment in order to differentiate among T. gondii, Neospora caninum, and Sarcocystis neurona. Genotyping was performed by multi-locus PCR-RFLP analysis of 13 markers (SU et al., 2006; PENA et al., 2008): SAG2-3' and SAG2-5' (HOWE et al., 1997); SAG3, GRA6, and SAG1; BTUB; L358; c22-8; c29-2; PK1; Apico; SAG2-alt; and CS3. The positive controls for the samples representing genotypes I, II, and III, as well as for those representing the atypical genotypes, were GT1, PGT, CTG, TgCgCa1, MAS, TgCatBr5, TgCatBr64, and TgRsCr1.

\section{Statistical analysis}

The statistical analysis was performed with the Epi Info program, version 6.04 (DEAN et al., 1994). Prevalence rates were calculated, and the associations among the results obtained were determined by the chi-square test. The level of significance was set at $5 \%$.

\section{Results}

Considering the IFAT and mouse bioassay results together, we detected $T$. gondii positivity in 60 of the 398 samples $(15.0 \%$; 95\% confidence interval: 11.7-18.9). Forty-six horses (11.6\%) were found to be positive for $T$. gondii by IFAT (Table 1), and 14 (3.5\%) were found to be positive for $T$. gondii by mouse bioassay. Twelve $(3.0 \%)$ of the mouse bioassays were found to be positive by IFAT, and we isolated the parasite in two bioassays because we found tachyzoites in the mouse peritoneal fluid or a cyst in a mouse brain (Table 2).

For the 14 horses that were found to be positive for $T$. gondii by mouse bioassay, we performed PCR on 20 biological samples (14 horse brain samples, three mouse peritoneal fluid samples, two mouse brain samples, and one mouse lung sample). As can be seen in Table 3, we found that three (14.3\%) of those samples tested positive: two horse brain samples and one mouse peritoneal fluid sample.

We found significant differences $(\mathrm{p}=0.0001)$ among the horses tested in terms of the prevalence of $T$. gondii positivity by region of origin, the lowest prevalence having been found among horses arriving from the central-west region of Brazil (Table 3). The use of PCR-RFLP with the $18 \mathrm{~S}$ rDNA marker revealed positivity for $T$. gondii alone in 3 horses (on the basis of samples 16,361 , and 404). The $T$. gondii isolates were not amplified in all of the markers used for genotyping, which was probably due to low DNA concentrations (Table 4).

\section{Discussion}

In the present study, $11.6 \%$ of the horses evaluated were found to test positive for $T$. gondii. This is in agreement with the findings

Table 1. Indirect fluorescent antibody test for Toxoplasma gondii in 398 serum samples from horses by origin (region and state), processed in slaughterhouses in the state of Paraná, Brazil, 2009-2010.

\begin{tabular}{|c|c|c|c|}
\hline \multicolumn{3}{|c|}{ Origin } & \multirow{2}{*}{$\begin{array}{c}\text { IFAT }^{*} \\
\text { POS/EXAM }^{1} \\
(\mathbf{n} / \mathrm{N})\end{array}$} \\
\hline Region & State & City & \\
\hline \multirow[t]{12}{*}{ South } & PR & Araruna & $1 / 4$ \\
\hline & PR & Borrazópolis & $1 / 4$ \\
\hline & PR & Cafezal do Sul & $1 / 15$ \\
\hline & PR & Campina Grande do Sul & $3 / 27$ \\
\hline & PR & Imbituva & $5 / 13$ \\
\hline & PR & Lobato & $4 / 33$ \\
\hline & PR & Londrina & $2 / 3$ \\
\hline & PR & Marquinho & $4 / 12$ \\
\hline & PR & Novo Itacolomi & $1 / 7$ \\
\hline & PR & Prudentópolis & $1 / 12$ \\
\hline & PR & Ribeirão Claro & $2 / 9$ \\
\hline & PR & Rio Bom & $2 / 2$ \\
\hline \multirow[t]{3}{*}{ Southeast } & MG & Itapagipe & $2 / 20$ \\
\hline & MG & Frutal & $5 / 33$ \\
\hline & $\mathrm{RJ}$ & Italva & $4 / 39$ \\
\hline \multirow[t]{5}{*}{ Central-west } & MS & Coronel Sapucaia & $2 / 10$ \\
\hline & MS & Deodápolis & $1 / 21$ \\
\hline & MT & Cáceres & $1 / 20$ \\
\hline & MT & Cuiabá & $4 / 17$ \\
\hline & & Total & $46 / 398(11.6 \%)$ \\
\hline
\end{tabular}

*IFAT = Indirect Fluorescent Antibody Test; POS/EXAM = positive/examined; $\mathrm{PR}=$ Paraná; $\mathrm{MG}=$ Minas Gerais $; \mathrm{RJ}=$ Rio de Janeiro; $\mathrm{MT}=$ Mato Grosso; MS = Mato Grosso do Sul; ${ }^{1}$ Number of sérum samples positive/examined for Toxoplasma gondii by IFAT; (cut-off titre $\geq 1: 64$ ). 
of Vidotto et al. (1997), who studied 561 serum samples from horses arriving (also for slaughter at one of the licensed slaughterhouses) from the states of Paraná, São Paulo, Mato Grosso, and Mato Grosso do Sul. Using IFAT, those authors found that $14.3 \%$ were positive for $T$. gondii. Even 15 years later, our findings are similar to theirs. Garcia et al. (1999) analyzed 173 serum samples from horses on farms in the city of Jaguapitá, Brazil, and found that the prevalence of $T$. gondii positivity was $12.1 \%$.

Table 2. Positivity for Toxoplasma gondii, as determined by mouse bioassay, in brain samples from 398 horses slaughtered in slaughterhouses in the state of Paraná, Brazil, 2009-2010.

\begin{tabular}{cccc}
\hline Origin & \multicolumn{2}{c}{ Horses } & Mouse \\
\hline Sample/city & IFAT & Brain & Bioassay \\
\hline TITRE* & PCR & \\
\hline 16/Prudentópolis & $1: 16$ & $\mathrm{P}$ & $\mathrm{P}^{1}$ \\
17/Prudentópolis & $\leq 1: 16$ & $\mathrm{~N}$ & $\mathrm{P}^{1}$ \\
20/Prudentópolis & $\leq 1: 16$ & $\mathrm{~N}$ & $\mathrm{P}^{1}$ \\
25/Campina Grande do Sul & $1: 16$ & $\mathrm{~N}$ & $\mathrm{P}^{1}$ \\
237/Lobato & $\leq 1: 16$ & $\mathrm{~N}$ & $\mathrm{P}^{1}$ \\
250/Novo Itacolomi & $1: 64$ & $\mathrm{~N}$ & $\mathrm{P}^{1}$ \\
264/Campina Grande do Sul & $1: 16$ & $\mathrm{~N}$ & $\mathrm{P}^{1}$ \\
361/Marquinho & $\leq 1: 16$ & $\mathrm{~N}$ & $\mathrm{P}^{2}$ \\
364/Marquinho & $\leq 1: 16$ & $\mathrm{~N}$ & $\mathrm{P}^{1}$ \\
404/Lobato & $\leq 1: 16$ & $\mathrm{P}$ & $\mathrm{P}^{3}$ \\
169/Paranaíba & $\leq 1: 16$ & $\mathrm{~N}$ & $\mathrm{P}^{1}$ \\
173/Paranaíba & $\leq 1: 16$ & $\mathrm{~N}$ & $\mathrm{P}^{1}$ \\
177/Paranaíba & $\leq 1: 16$ & $\mathrm{~N}$ & $\mathrm{P}^{1}$ \\
299/Italva & $\leq 1: 16$ & $\mathrm{~N}$ & $\mathrm{P}^{1}$ \\
\hline
\end{tabular}

IFAT = Indirect fluorescence antibody test; $\mathrm{PCR}=$ polymerase chain reaction; $\mathrm{P}=$ Positive, $\mathrm{N}=$ Negative; ${ }^{*}$ cut-off titre $\geq 1: 64 ; 1$. IFAT cut-off titre $\geq 1: 16$; 2. Isolation of tachyzoites in peritoneal fluid of mouse; 3. Isolation of brain cysts in mouse.

Table 3. Positivity for Toxoplasma gondii, as determined by indirect fluorescent antibody test and mouse bioassay, in horses processed in slaughterhouses in the state of Paraná, Brazil, 2009-2010, by origin (region and state).

\begin{tabular}{ccc}
\hline & Origin & T. gondii $^{*}$ \\
\hline Region & State & $\begin{array}{c}\text { Positive/total } \\
\text { n/N (\%) }\end{array}$ \\
\hline South & Paraná & $37 / 152(24.2)$ \\
Southeast & Minas Gerais and Rio de Janeiro & $12 / 92(13.0)$ \\
Central- & Goiás, Mato Grosso do Sul, & $11 / 154(7.1)$ \\
west & and Mato Grosso & $60 / 398(15.0)$ \\
& Total & \\
\hline
\end{tabular}

${ }^{*} \mathrm{p}=0.0001$.
Mendonça et al. (2001) used IFAT in order to test 343 samples from horses from two regions of Bahia, Brazil, and found that 1.5\% were positive for $T$. gondii. Naves et al. (2005) analyzed 117 serum samples from Mangalarga horses on three stud farms in Uberlândia, Brazil, and found the prevalence of $T$. gondii positivity to be $5.1 \%$. Camossi et al. (2010) tested 253 serum samples from horses in Botucatu, Brazil, and found the prevalence of $T$. gondii positivity to be $0.4 \%$. However, Larangeira et al. (1985) used IFAT to evaluate 750 horses on farms in the state of Mato Grosso do Sul and found $27.6 \%$ prevalence of $T$. gondii positivity.

The above mentioned differences might be due to various factors: equine resistance to infection; environmental conditions; the strain of $T$. gondii; the type of feed given and the source of the water provided; and the population density of domestic or wild cats in the environment (KIJLSTRA; JONGERT, 2009; KOUAM et al., 2010; MENDONÇA et al., 2001; NAVES et al., 2005; TENTER et al., 2000; VIDOTTO et al., 1997). According to Kouam et al. (2010), the type of activity and the geographic location of the horses have a significant effect on the development of $T$. gondii infection.

In the present study, horses that were found to be positive for $T$. gondii by mouse bioassay were not found to be positive by IFAT. In a study conducted in Australia, in which the authors used the latex agglutination test in order to test serum samples from a female dog and her six puppies for $T$. gondii. The dog tested negative, and the results of all of the tests performed subsequently (including those of those performed up to six months after the birth of the six puppies) were also negative. However, Western blotting and PCR showed evidence that the dog had been infected with T. gondii. Although the latex agglutination test revealed that the six puppies were negative for T. gondii, PCR showed that they had T. gondii DNA in their brain tissue (AL-QASSAB et al., 2009).

Araújo et al. (2010) studied 43 rodents in the urban area of Umuarama, Brazil, using blood samples for the modified agglutination test, as well as brain and heart samples for bioassay. Although all of the rodents tested negative for anti- $T$. gondii antibodies, the parasite was isolated in one mouse (Mus musculus) and one rat (Rattus rattus).

According to Dubey et al. (1999), the risk of becoming infected with $T$. gondii by consuming horse meat is low because the prevalence of $T$. gondii in horses is low. However, the previously mentioned case of congenital toxoplasmosis in an infant born to a pregnant woman who probably ate raw horse meat in France (ELBEZ-RUBINSTEIN et al., 2009), together with the fact that there have been few studies employing bioassay to screen for toxoplasmosis in horses, reignites this discussion. In the present

Table 4. Multi-locus genotyping (polymerase chain reaction- restriction fragment length polymorphism) of Toxoplasma gondii strains isolated from horses processed in slaughterhouses.

\begin{tabular}{cccccccccccccc}
\hline ISOLATE & CS3 & SAG1 & 5-3SAG2 & alt.SAG2 & SAG3 & BTUB & GRA6 & c22-8 & C29-2 & L358 & PK1 & APICO \\
\hline $16^{1}$ & NA & I & I & I & III & I & NA & NA & NA & NA & NA & NA \\
$361^{2}$ & NA & I & I & II & III & II & NA & I & NA & NA & I & NA \\
$404^{3}$ & NA & II/III & I & I & III & I & I & NA & NA & I & NA & NA \\
\hline
\end{tabular}

NA = not amplified; ${ }^{1}$ DNA extracted from horse brain; ${ }^{2}$ Tachyzoites in mouse peritoneal fluid; ${ }^{3}$ Bradyzoites in mouse brain. 
study, we found brain cysts and tachyzoites in mice inoculated with macerated horse brain. This provides evidence that tissue cysts in horses can transmit $T$. gondii.

Although the Brazilian National Ministry of Agriculture, Animal Husbandry, and Supply Food Safety and Inspection Service complies with the international standards regulating horse meat, $T$. gondii cysts are invisible to the naked eye. In order to prevent $T$. gondii infection, the meat should be stored frozen and subsequently cooked appropriately. The cysts found in contaminated meat can be destroyed by storing the meat at $-20{ }^{\circ} \mathrm{C}$ for $18-24$ hours (REMINGTON et al., 1995).

If we take into consideration the fact that horse meat production involves the slaughter of horses raised in a variety of ways and under varying sanitary conditions, quality management in horse breeding can aid in reducing the risk of infection with etiologic agents such as $T$. gondii, which can be transmitted by eating meat or viscera, in regions where horse meat is habitually consumed. On July 1, 2010, the slaughterhouses licensed by the Brazilian National Ministry of Agriculture, Animal Husbandry, and Supply had to make adjustments in order to comply with new guidelines, which include the requirement for horses to have remained on the same farm for six months before slaughter, as well as for the owners of those farms to maintain a list of the veterinary drugs used during that period. From a food safety standpoint, the fact that Brazil devised a plan in order to meet the new requirements and, more importantly, the fact that the plan was approved by the Food and Veterinary Office of the European Union indicate that a great effort was made in order to avoid sanctions (MOREIRA, 2010).

Although it is not consumed by Brazilians, horse meat from Brazil constitutes a route of transmission of $T$. gondii to humans in other locations. Some of the horses investigated in the present study were found to have been infected with $T$. gondii. Mouse bioassay and PCR demonstrated the presence of $T$. gondii in horse brain, which suggests the presence of cysts in other organs, as well as in muscles. Our results show that some horses sent to slaughter in Brazil have been exposed to T. gondii.

\section{References}

Al-Qassab S, Reichel MP, Su C, Jenkins D, Hall C, Windsor PA, et al. Isolation of Toxoplasma gondii from the brain of a dog in Australia and its biological and molecular characterization. Vet Parasitol 2009; 164(2-4): 335-339. PMid:19556061. http://dx.doi. org/10.1016/j.vetpar.2009.05.019

Araújo JB, Silva AV, Rosa RC, Mattei RJ, Da Silva RC, Richini-Pereira $\mathrm{VB}$, et al. Isolation and multilocus genotyping of Toxoplasma gondii in seronegative rodents in Brazil. Vet Parasitol 2010; 174(3-4): 328-331. PMid:20869811. http://dx.doi.org/10.1016/j.vetpar.2010.08.039

Brasil. Ministério da Agricultura, Pecuária e Abastecimento. Relação de Produtos Autorizados para os Estabelecimentos Brasileiros Exportarem por País [on line]. [cited 2012 jan 05]. Available from: http://bi.agricultura. gov.br/reports/rwservlet?sigsif_cons\&prod_aut_estab_bra_exp_pais. rdf\&p_id_pais=\&p_id_mercado_comum=\&p_id_area=1\&p_id_ produto $=73 \&$ p_serial $=634567468$ paramform $=$ no.

Camargo ME. Introdução às técnicas de imunofluorescência. Rev Bras Patol Clin 1974; 10(4): 143-171.
Camossi LG, Silva AV, Langoni H. Inquérito sorológico para toxoplasmose em equinos na região de Botucatu-SP. Arq Bras Med Vet Zootec 2010; 62(2): 484-488. http://dx.doi.org/10.1590/S010209352010000200032

Da Silva RC, Langoni H, Su C, Da Silva AV. Genotypic characterization of Toxoplasma gondii in sheep from Brazilian slaughterhouses: new atypical genotypes and the clonal type II strain identified. Vet Parasitol 2011; 175(1-2): 173-177. PMid:20970257. http://dx.doi. org/10.1016/j.vetpar.2010.09.021

Dean AG, Dean JA, Coulombier D, Brendel KA, Smith DC, Burton $\mathrm{AH}$, et al. Epi Info. version 6: a word processing, database, and statistic program for epidemiology on microcomputers. Atlanta: CDC; 1994.

Dubey JP, Weigel RM, Siegel AM, Thulliez P, Kitron UD, Mitchell MA, et al. Sources and reservoirs of Toxoplasma gondii infection on 47 swine farms in Illinois. J Parasitol 1995; 81(5): 723-729. PMid:7472862. http://dx.doi.org/10.2307/3283961

Dubey JP, Thulliez P, Romand S, Kwok OCH, Shen SK, Gamble HR Serologic prevalence of Toxoplasma gondii in horses slaughtered for food in North America. Vet Parasitol 1999; 86(4): 235-238. http://dx.doi. org/10.1016/S0304-4017(99)00148-X

Dubey JP, Su C. Population biology of Toxoplasma gondii: what's out and where did they come from. Mem Inst Oswaldo Cruz 2009; 104(2): 190-195. PMid:19430643. http://dx.doi. org/10.1590/S0074-02762009000200011

Elbez-Rubinstein A, Ajzenberg D, Dardé ML, Cohen R, Dumètre A, Yera $\mathrm{H}$, et al. Congenital Toxoplasmosis and reinfection during pregnancy: case report, strain characterization, experimental model of reinfection, and review. J Infect Dis 2009; 199(2): 280-285. PMid:19032062. http:// dx.doi.org/10.1086/595793

Garcia JL, Navarro IT, Ogawa L, De Oliveira RC. Soroprevalência do Toxoplasma gondii, em suínos, bovinos, ovinos e eqüinos, e sua correlação com humanos, felinos e caninos, oriundos de propriedades rurais do norte do Paraná-Brasil. Cienc Rural 1999; 29(1): 91-97. http://dx.doi. org/10.1590/S0103-84781999000100017

Howe DK, Honoré S, Derouin F, Sibley LD. Determination of genotypes of Toxoplasma gondii strains isolated from patients with toxoplasmosis. $J$ Clin Microbiol 1997; 35(6): 1411-1414. PMid:9163454 PMCid:229759.

Inacio A. SP: Exportador de carne de cavalo de olho na China. Canal do Produtor, Notícias de Mercado [on line]. 2010. [cited 2011 jan 07]. Available from: http://canaldoprodutor2.talk2.com.br/comunicacao/ noticias/sp-exportador-de-carne-de-cavalo-de-olho-na-china

Junqueira ACA, Bressan MC, Rebello FFP, Faria PB, Vieira JO, Savian TV. Composição centesimal e teor de colesterol na carne de eqüinos (Equus caballus, Linneaus, 1758) machos e fêmeas agrupados por peso de carcaça. Ciênc Agrotec 2005; 29(2): 362-368. http://dx.doi.org/10.1590/ S1413-70542005000200013

Kijlstra A, Jongert E. Toxoplasma-safe meat: close to reality? Trends Parasitol 2009; 25(1): 18-22. PMid:18951847. http://dx.doi. org/10.1016/j.pt.2008.09.008

Kouam MK, Diakou A, Kanzoura V, Papadopoulos E, Gajadhar AA, Theodoropoulos G. A seroepidemiological study of exposure to Toxoplasma, Leishmania, Echinococcus and Trichinella in equids in Greece and analysis of risk factors. Vet Parasitol 2010; 170(1-2): 170-175. PMid:20197215. http://dx.doi.org/10.1016/j.vetpar.2010.02.004

Larangeira NL, Ishizuka MM, Mizuno M, Hyakutake S. Prevalência da toxoplasmose eqüina avaliada pela técnica de imunofluorescência indireta, 
Mato Grosso do Sul, Brasil. Bol Oficina Sanit Panam 1985; 99(2): 158162. PMid:2935168.

Macedo MFSB, Macedo CAB, Ewald MPC, Martins GF, Zulpo DL, Cunha IAL, et al. Isolation and genotyping of Toxoplasma gondii from pregnant dairy cows (Bos taurus) slaughtered. Rev Bras Parasitol Vet 2012, 21(1): 74-77. PMid:22534951. http://dx.doi.org/10.1590/ S1984-29612012000100016

Medeiros JF. UE Tem Novas Regras Para Importar Carne Eqüídea. Canal do Produtor [on line]. 2009 [cited 2011 jan 18]. Available from: http:// www.canaldoprodutor.com.br/comunicacao/artigos/ue-tem-novasregras-para-importar-carne-equeidea

Mendonça AO, Cerqueira EJL, Araujo WN, Moraes-Silva E, Shimabukuro FH, Sarkis DT, et al. Inquérito sorológico para toxoplasmose em equídeos procedentes de duas regióes do Estado da Bahia, Brasil. Semina: Cienc Agrar 2001; 22(2): 115-118.

Moreira A. UE aprova rastreamento para cavalos. Canal do Produtor [on line]. 2010. [cited 2011 jan 07]. Available from: http://www. canaldoprodutor.com.br/comunicacao/noticias/ue-aprova-rastreamentopara-cavalos .

Navarro IT, Vidotto O, Giraldi N, Freire RL. Toxoplasma gondii isolamento a partir de carne e cérebro de suínos comercializados na região de Londrina - PR. Semina: Cienc Agrar 1992; 13(1): 32-34.

Naves CS, Ferreira FA, Carvalho FSR, Costa GHN. Soroprevalência da toxoplasmose em equinos da raça Mangalarga marchador no município de Uberlândia, Minas Gerais. Vet Not 2005; 11(1): 45-52.

Pena HFJ, Gennari SM, Dubey JP, Su C. Population structure and mouse-virulence of Toxoplasma gondii in Brazil. Int $J$ Parasitol 2008, 38(5): 561-569. PMid:17963770. http://dx.doi. org/10.1016/j.ijpara.2007.09.004
Remington JS, McLeod R, Desmonts G. Toxoplasmosis. In: Remington JS, Klein JO, editors. Infectious diseases of the fetus and newborn infant. 4th ed. Philadelphia: Saunders; 1995. p. 140-167.

Su C, Zhang X, Dubey JP. Genotyping of Toxoplasma gondii by multilocus PCR-RFLP markers: A high resolution and simple method for identification of parasites. Int J Parasitol 2006; 36(7): 841-848. PMid:16643922. http://dx.doi.org/10.1016/j.ijpara.2006.03.003

Su C, Shwab EK, Zhou P, Zhu XQ, Dubey JP. Moving towards an integrated approach to molecular detection and identification of Toxoplasma gondii. Parasitol 2010; 137: 1-11. PMid:19765337. http:// dx.doi.org/10.1017/S0031182009991065

Tenter AM, Heckeroth AR, Weiss LM. Toxoplasma gondii: from animals to humans. Int J Parasitol 2000; 30(12-13): 1217-1258. http://dx.doi. org/10.1016/S0020-7519(00)00124-7

Torres AP, Jardim WR. Criação de cavalos e outros equídeos. 3rd ed. São Paulo: Nobel, 654p; 1987.

Tsutsui VS, Freire RL, Garcia JL, Gennari SM, Vieira DP, Marana ERM, et al. Detection of Toxoplasma gondii by PCR and mouse bioassay in commercial cuts of pork from experimentally infected pigs. Arq Bras Med Vet Zootec 2007; 59(1): 30-34. http://dx.doi.org/10.1590/S010209352007000100006

Vidotto O, Kano FS, Freire RL, Mitsuka R, Ogawa L, Bonesi G, et al. Ocorrência de anticorpos anti-Toxoplasma gondii em eqüinos procedentes de quatro Estados (SP, PR, MS e MT) abatidos em Apucarana, PR. Semina: Cienc Agrárias 1997; 18(1): 9-13.

Yai LEO, Ragozo AMA, Soares RM, Pena HFJ, Su C, Gennari SM. Genetic diversity among capybara (Hydrochaeris hydrochaeris) isolates of Toxoplasma gondii from Brazil. Vet Parasitol 2009; 162(3-4): 332-337. PMid:19375864. http://dx.doi.org/10.1016/j.vetpar.2009.03.007 